England according to a forthcoming paper by Dr. W. A. Sledge in Watsonia).

Finally, a probable Early Iron Age dating for the monoxylous 'Shapwick Boat' is based upon the pollen-analysis of a sample of peat taken from the boat, and rounds off very neatly these outstanding contributions to the history of primitive man and his environment in Somerset.

H. G. BAKER

\section{PLASTICS INDUSTRY IN SCOTLAND*}

$\mathrm{T}$ HE reconstituted Committee on Plastics appointed by the Scottish Council (Development and Industry) was appointed to inquire further into the extent to which the industry is being developed in Scotland to meet requirements, to suggest what further action is required to meet the situation, and to consider in particular the possibilities of meeting the basic requirements of the industry from raw materials in Scotland. In its final report, the Committee states that while more firms are now manufacturing finished materials from moulding powders obtained from elsewhere, and the engineering industry is in a position to tackle the highly specialized side of mould fabrication without difficulty, no developments of any kind have occurred in the manufacture of the ingredients of the moulding powders. No plastics industry can be firmly established in Scotland while these raw materials have to be imported, and the supply of coal-tar phenol and cresols is quite inadequate to meet the needs of the plastics and other industries of the United Kingdom.

The Committee recommends, therefore, that the Ministry of Supply be reminded of the urgent need for synthetic phenol, and that ample benzene and sulphuric acid are available in Scotland for the purpose. The supply of toluene is also adequate, and the sulphonation process is regarded as more attrac. tive. Royal ordnance explosives factories in the west of Scotland appear to offer the most convenient sites for the manufacture of these phenols, and the Com. mittee also recommends that the Director of Ordnance Factories should be informed accordingly. The Tar Research Association should be invited to explore methods for efficient recovery of such products as $o$-xylene and naphthalene for phthalic anhydride manufacture, and the Ministry of Supply should also be asked to consider the possibility of manufacturing methyl alcohol in Scotland as soon as the fertilizer situation is relieved.

The increasing use of plastics of the polyvinyl chloride, methacrylate and other types focuses attention on the unsaturated gases, acetylene and ethylene. The oil-refining and shale-oil industries could produce large volumes of ethylene and propylene in plant now available in Scotland, and the Com. mitte accordingly recommends that the plastics and chemical industries should be advised that adequate amounts of unsaturated gases of the required purity for the manufacture of plastics and of antiseptics, insecticides, detergents and synthetic rubbers could be made available from the petroleum-refining and shale-oil industries and from coal carbonization in Scotland. Ethylene could also be recovered from cokeoven gas without seriously affecting the calorific

Final Report of the Committee on Plastics: Plastics in Scotland. Pp. 16. (Edinburgh: Scottish Council (Development and Industry), 20 George Street, 1948.) 28. value of the gas for most industrial purposes, and the Committee recommends that the coke manufacturers be encouraged to investigate this possibility.

Since five per cent of the estimated power of the hydro-electric schemes set apart for calcium carbide manufacture would make a substantial contribution to the needs of the plasties industry in Scotland for acetylene, it is recommended finally that the Secretary of State be informed of the urgent need of an established carbide industry in Scotland for chemical as well as engineering purposes. The Committee concludes by pointing out that the rapidly increasing developments in the manufacture of flexible plastic materials emphasizes the need for a wide range of suitable plasticizers, none of which is at present made in Scotland.

The economic aspects of the whole situation are not discussed in this report; this may well draw serious criticism from the economists for neglect of an essential factor.

\section{THE NATIONAL FOUNDATION FOR ADULT EDUCATION}

$T$ HE National Foundation for Adult Education has now been constituted since January 1947 and, besides its quarterly bulletin, Foundation Papers, has published various supplements dealing with subjects of immediate importance to its corporate members.

One supplement, "Voluntary Agencies in Adult Education", contains a summary of the aims and activities of voluntary bodies working in the field of adult education. Since there is no up-to-date and comprehensive directory of adult education, the information contained in this supplement should be of particular use to local education authorities in coming to grips with the development plans for further education which they bave been asked to prepare. "Voluntary Agencies in Adult Education" will also be useful as a reference for individuals who are interested in various aspects of adult education. The supplement contains no reference to the work of university extra-mural departments and tutorial class committees, and it is intended that these should be considered in a later supplement.

The second supplement, called "Sources of Visual Aid Material : For use in the Adult Teaching of History and Contemporary Affairs", has been compiled by the deputy director, Extra-Mural Depart. ment, University of Manchester. The information has been collected partly at the request of the Associa. tion of Tutors in Adult Education and partly to meet the needs of tutors of the Manchester University Extra-Mural Department. It should also be useful to leaders of discussion groups and others concerned with adult education classes. The booklet contains a list of maps and charts, films, filmstrips, lantern slides and other pictorial material which would be suitable for adult classes of a general historical and geographical nature, and also a list of material suitable for teachers dealing with particular periods and countries.

Another supplement, "Accommodation for Adult Education : Some Examples and Suggestions", discusses an issue which presents difficulties to all the co-operating parties in adult education. A recent pamphlet of the Ministry of Education stated that : "Up and down the country there are a few colleges 
for further education which are noused in worthy buildings of dignity and beauty. But these are oases in the desert. For the most part there is a great dearth of educational accommodation of every kind from college to village hall, and further education, whether formal or informal, full-time or part-time, has at present to contend with most unsuitable premises." The National Foundation for Adult Education began in 1947 to collect information about the present availability of accommodation, and in this pamphlet it has brought together examples of improvisation at various levels, together with examples of more permanent provision. A short directory of the new short-term residential accommodation has also been included.

Because the literature about them is both brief and, in the main, out of date, some notes are included on the Cambridgeshire village colleges. These are one of the few working examples of combined educa tional provision, a subject which is being discussed in some detail to-day by the majority of local education authorities. The pamphlet should be useful in stimulating local education authorities and voluntary organisations to make a more searching examination of local possibilities for making more premises 'inter-available'.

T. H. HawkINS

\section{FORTHCOMING EVENTS}

Tuesday, December 28

ROYAL INSTITUTION (at 21 Albemarle Street, London, W.1), at 3 p.m.- Sir Frederic Bartlett, F.R.S : "The Mind at Work and at Play-Experiments in Psychology'"

(Further Lectures on December 30 , January 1, 4, 6 and 8.)

Wednesday, December 29

ROYAL GROGRAPHICAL SOCIETY (at Kensington Gore, London, S.W.7), at 2.30 p.m.-Mr. Tames Fisher and Dr. Ludwig Koch. "Exploring Britain's Islands". (Christmas Meeting for Young People.)

Thursday, December 30

Institution of CIVIL ENGINEERS (at Great George Street, London, S.W.1), at 3 p.m.-Mr. J. Melville: "Big Ships and their Docks-1, Building Big Ships" (Christmas Lectures to Boys.)

(Further Lectures on Monday, January 3, and Tuesday, January 4.

\section{APPOINTMENTS VACANT}

APPLICATIONS are invited for the following appointments on or before the dates mentioned :

SENIOR RESEARCH OFFICER, and RESEARCH OFFICERS (3), in the Pasture Research Division of the Department of Agriculture and Lands, Southern Rhodesia-The Secretary to the High Commissioner for Southern Rhodesia, Rhodesia House, 429 Strand, London, W.C.2 for Southern R

SCIENTISTS (with University qualiflcations in one or more of the subjects of physics, chemistry, zoology, engineering, botany, agriFestival of Britain 1951-The Technical and Scientific Register (K), York House, Kingsway, London, W.C.2, quoting A.321/48A (December 31 ).

LECTURER IN THE ELECTRICAL ENGINGERING DEPARTMENT-The Clerk to the Governors, Woolwich Polytechnic, Woolwich, London, S.E.18 (January 1)

RESEarch Fellowship in the DepartMment of Chemical ENGINEERING AND APPLIED CHEMISTRY - The Secretary, Imperial College of Science and Technology, South Kensington, London, S.W.7 (January 1).

ENGINEAR II (unestablished) at a Ministry of Supply Research and Development Establishment, to take charge of experimental work in testing explosives and demolition equipment, etc.- The Ministry of Labour and National Service, Technical and Scientific Register (K), York House, Kingsway, London, W.C.2, quoting E.569/48 (January 7)

Physical CHEMast to take part in an investigation of tissue proteins and related problems-The House Governor and Secretary, Royal Cancer Hospital, Fulham Road, London, S.W.3 (January 11). PROFESSOR OF ASTRONOMY-The Dean, Faculty of Science, Fouad I PROFESSOR OF ASTRONOMY-The Dean,

niversity, Cairo, Egypt (January 15). GRADUATE with research experience in Organic Chemistry, for
micro-analytical work, including teaching and research-The Regismicro-analytical work, including teaching and research-The Regis, The University, Liverpool (.Tanuary 15).

SENIOR LECTURER Or LECTURER IN ANATOMY-The Registrar, The
University, Sheffield (January 22).
CHaIR OF PHLLOSOPHY in the University of Bern-Die Kantonale Erziehungsdirektion, Münsterplatz 3a, Bern, Switzerland (January 31). DIRECTOR OF RESEAROH of the Australian Leather Research Associa tion, Sydney-Mr. A. Harvey, Craigieburn, Duppas Hill Road, Croydon, Surrey.

BOTANIST in the East African Tsetse Reclamation Department Kenya-The Director of Recruitment, Colonial Service, Colonial Office, Great Smith Street, London, S.W.1.

HONOURS B.SC. PHYSICIST FOR RADIOTHERAPY DEPARTMENT-The Administrative Officer, Royal Berkshire Hospital, Reading, endorsed 'Appointment of Physicist'.

ENTOMOLOGISTS (2) IN THE DEPARTMENT OF AGRICULTURE, Kenya -The Director of Recruitment, Colonial Service, Colonial Office, Great Smith Street, London, S.W.1.

SOIL SURVEY OFFICERS (3) in the Gold Coast to supervise the collection of information about the soils of the forest region in that territory-The Director of Recruitment, Colonial Service, Colonial Office, Great Smith Street, London, S.W.1.

BIOCHEMIST to the Reading Group of Hospitals-The Administrative Officer, Royal Berkshire Hospital, Rearling, endorsed 'Appointment of Biochemist'.

JUNIOR GRADUATE for biochemical work at Elstree, Herts-The Secretary, Lister Institute of Preventive Medicine, Chelsea Bridge Road, Iondon, S.W.1.

CRREALIST for the Directorate-General of Agriculture, Government of Iraq-The Crown Agents for the Colonies, 4 Millbank, London, S.W.1, quoting M.N.18187/3C

PHYSICIST to investigate physical properties of dairy products, especially liquid milk-The Secretary, National Institute for Research in Dairying, Shinfleld, Reading.

ASSISTANT ENGINEER or TECHNICHAN to assist in the maintenance of several 200-kilovolt $\underset{X}{X}$-ray installations-The Secretary, Mount Vernon Hospital and the Radium Institute, Northwood, Middx.

PHYSICIST (preferably with some research experience) to study rheological properties of yarns and flaments-The Secretary, British Manchester 1.

Manchester 1.

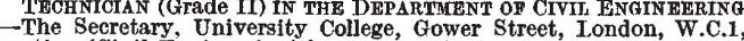
quoting 'Civil Engineering/1'.

CHAIR OF ZoOLOGY - The Registrar, The University, Nottingham.

\section{REPORTS and other PUBLICATIONS}

(not included in the monthly Books Supplement)

\section{Great Britain and Ireland}

Question: a Journal. Edited by H. Westmann. Vol. 1, No. 1, July 1948: The Critical Problem in Human Relationships Today. By G. Wilson Knight, Herbert Read and Dr. J. H. Oldham. Pp. 87. (Published for the Present Question Conference, Ltd.) (London: The Identification of Textile Materials.) 28. 6d. net. [238 Technology, No. 3.) Pp. $12+14$ plates. (Manchester: Textile Institute, 1948.) 58. 5 [238 National Building Studies. Bulletin No. 2 : Painting New Plaste 9 plates. 18. net. Special Report No. 3: Sand-Lime Bricks. By 9 plates. 18. net. Special Report No. 3 : Sand-Lime Bricks. By G. E. Bessey, Pp. V $+58+3$ plates. 18. 3d. net. (London: H.M.
Stationery Ofice, 1948.) Ministry of Education and the Scottish Education Department Ministry of Education Pamphlet No. 12: UNESCO and a World Society. Pp. 46. (London: H.M. Stationery Office, 1948.) 18. net. British Standard 1170: 1947. British Standard for Treatment of Water for Marine Boilers (with a Section on Engineering Factors). Pp. 96. (London: British Standards Institution, 1947.) 108. 6d.
net.
[268

\section{Other Countries}

The Waipoua Forest : the Last Virgin Kauri Forest of New Zealand. By W. R. McGregor. Pp. 80. (Auckland: The Author, Department of Zoology, University College, 1948.) 58. Physics To-day. (Monthly.) Vol. 1, No. 1, May 1948. Pp. 40 (New York : American Institute of Physics, 1948.) 50 cents ; annua]
subscription, 5 dollars. $[238$
Smithsonian Institution: United States National Museum. Bulletin Smithsonian Institution: United States National Museum. Bulletin
194: An annotated Checklist and Key to the Amphibia of Mexfco. 194 : An annotated Checklist and Key to the Amphibia of Mexico. ton, D.C.: Government Printing Office, 1948.) 50 cents. [238 Annual Report of the All-India Institute of Hygiene and Public Health, Calcutta, 1944-45. Pp. vili +56 . (Calcutta : All-India Institute of Hygiene and Public Health, 1948.) [248 International Chamber of Commerce. Brochure No. 126: Administrative Assistance for Tax Collection and Assessment (Counci Resolution, June 1948); Report of the I.C.C.'s Committee on Taxation on the League of Nations Model Bilateral Convention (London Draft) Pp. ii +22. (Paris: International Chamber of Commerce, 1948.) [248

\section{Catalogues}

Murfume DDT and Azobenzene Smokes for Horticultural Use. Pp. 4. (Wheathampstead : Murphy Chemical Co., Ltd., 1948.)

Catalogue of New Books on Mathematics, Physics, Astronomy and Meteorology. Pp. 40. (London: H. K. Lewis and Co., Itd., 1948.) Catalogue of New Books on the

H. K. Lewis and Co., Ltd., 1948.) BBC-Marconi Ribbon Microphone Type AXBT. (Ref. SL.36.) Pp. 8. BBC-Marconi Ribbon Microphone Type AXBT. (Ref. SL.36.) Pp. 8 .
$3 \mathrm{~kW}$. Transmitter Type TGM651. (Ref. SL.35.) Pp. 4. Telegraphy$3 \mathrm{~kW}$. Transmitter Type TGM 651. (Ref. SL.35.) Pp. 4. Telegraphy;
Telephony Transmitters TGM 571 and TGS571. (Ref. SL.17/2.) Pp. 4. Receiver Type CR300. (Ref. SL.4/2.) Pp. 4. Receiver Type $C R 100 / 2$.
Telegraph Co., Ltd., 1948. 